European Journal of Turkish Studies

Social Sciences on Contemporary Turkey

4 | 2006

THEMATIC ISSUE

The social practices of kinship. A comparative perspective

\title{
'How a Kaynana Should Behave?' Discussions on the Role of Mothers-in-Law in Two Gün Groups
}

Berna Ekal

\section{(2) OpenEdition}

Journals

Electronic version

URL: http://journals.openedition.org/ejts/619

DOI: $10.4000 /$ ejts.619

ISSN: $1773-0546$

Publisher

EJTS

\section{Electronic reference}

Berna Ekal, «'How a Kaynana Should Behave?' Discussions on the Role of Mothers-in-Law in Two Gün Groups », European Journal of Turkish Studies [Online], 4 | 2006, Online since 05 March 2015,

connection on 16 February 2020. URL : http://journals.openedition.org/ejts/619 ; DOI : 10.4000/ejts. 619 
Citation : Ekal, Berna (2006) 'How a Kaynana Should Behave?' Discussions on the Role of Mothers-in-Law in Two Gün Groups', European Journal of Turkish Studies, Thematic Issue $N^{\circ} 4$, The social practices of kinship. A comparative perspective, URL : http://www.ejts.org/document619.html

To quote a passage, use paragraph (§).

\title{
'How a Kaynana Should Behave?' \\ Discussions on the Role of Mothers-in-Law in Two Gün Groups \\ Berna Ekal
}

\begin{abstract}
Gün (day), as a specific form of rotating savings and credit associations in urban Turkey, is a distinct ground for women where middleclass values and norms are performed. In this context, the discussions on being a kaynana (mother-in-law) help us to consider the ways in which the notion of conjugal family is central to the self-perception of women. To oppose the role of kaynanas 'in the past' is women's way of claiming to comply with what they perceive to be the 'modern' way of forming a family and, hence, of being 'modern'. This, in turn, helps us to reconsider the ways in which kinship roles are elaborated in different contexts and shows that the ideas about the proper kinship roles shape the relation of people to the people other than their kin.
\end{abstract}


Ekal, Berna (2006) 'How a Kaynana Should Behave?' Discussions on the Role of Mothers-in-Law in Two Gün Groups', European Journal of Turkish Studies, Thematic Issue $\mathrm{N}^{\circ} 4$, The social practices of kinship. A comparative perspective, URL : http://www.ejts.org/document619.html

To quote a passage, use paragraph $(\S)$.

In this paper, I discuss the position of being a kaynana ${ }^{1}$ as it is elaborated by women in two gün${ }^{2}$ groups in a middle-class district in Istanbul. Most of the women in the gün meetings have married children and experienced rural to urban migration either before or after their marriage. I argue that, for these women, the discussions in gün groups about the relations between mothers-inlaw and brides / grooms provide a certain ground in which women claim to comply with 'contemporary' norms, which women identify to be in contrast to the norms when they were young brides, as indicated in the expression 'şimdi başka türlü tabii" ${ }^{3}$. This feeling of contemporaneity is distinctive of the perception of 'modern', as can be explained with regards to Mitchell's argument that 'a distinctive feature of many experiences of modernity is what can be called its contemporaneity or presence' (2000: 14). What I would like to emphasize in this article is that this feeling of contemporaneity unfolds in the presentation of self. In gün meetings, presentation of the self proceeds through many resources, such that a woman might assert her care for the cleanliness of her house or her ability to cook, all of which might become a way of showing that she fulfils the requirements of 'modern' middle-class womanhood. Yet, this tableau is accompanied by a corresponding narrative as well. Regardless of what 'actually' women might be experiencing with their daughter-in-laws, talking about their relations with them constitutes a significant component of their self-presentation as 'modern' women, or as 'modern' mothers-in-law, in the gün meetings.

[2] With reference to Abu-Lughod (2000), Mitchell argues that 'selfhood comes to be fashioned by staging one's life as a story, in a continuous representation of oneself to oneself and others' (2000: 21). In the course of a gün meeting, the life stories of women may not unfold totally. Yet, these stories provide a frame of reference in the way in which their experiences with their brides are exchanged and rethought. This brings us to the idea that 'the central concern is not how narrative as text is constructed but rather how it operates as an instrument of the mind in the construction of reality' (Bruner 1991: 6). Hence, I argue that in talking and sharing memories of their mother-in-law, as in the interviews, and exchanging their experiences with their daughter-in-laws, as in the gün

\footnotetext{
${ }^{1}$ Turkish word for 'mother-in-law'. Kayınvalide is also used in Turkish and is often considered to be more polite form of addressing the mother-in-law.

2 Gün, literally, means 'day'. Its specificity is explained in the rest of the text.

3 'Now it is different, of course' (my translation).
} 
Ekal, Berna (2006) 'How a Kaynana Should Behave?' Discussions on the Role of Mothers-in-Law in Two Gün Groups', European Journal of Turkish Studies, Thematic Issue $\mathrm{N}^{\circ} 4$, The social practices of kinship. A comparative perspective, URL : http://www.ejts.org/document619.html

To quote a passage, use paragraph $(\S)$.

meetings, women narrate their understanding of modernity. As Rofel also argues, 'modernity exists as a narrated imaginary: it is a story people tell themselves about themselves in relation to others' (1999: 13). Therefore, to oppose the role of kaynanas 'in the past' is women's way of claiming to comply with what they perceive to be the 'modern' way of forming a family. Now, for a mother in-law, her relation to the wife of her son / the husband of her daughter becomes a defining feature of her self-perception as an urbane, considerate, or proper person. Conjugal family, as the norm of modernity', is at the root of this collective self-understanding.

\section{Gün as a Women's Association}

[3] I was introduced to the two gün groups by Sevgi hanım in November, 2004. I attended several of their meetings and later conducted interviews with some of the participants. The first group of women organized gün among themselves for fifteen years and was composed of ten women, aged $45-65$, among them seven have married children. Sevgi hanım called her other group of gün as akraba günü ('kin day') as her husband's three sisters were a part of that group. This was rather a small group, consisting of seven women, aged $40-60$, among them five have married children. Except for one of the eltis (wives of brothers) in the first gün group, all of these women are Alevi, coming from nearby villages or towns. The gün meetings, however, is by no means a practice restricted to Alevi women. It is a common activity among women in urban areas, and surely it takes different forms / has diverse dynamics in terms of the participants, the amount of the contributions and other practices within the gün meetings.

[4] Gün (day) is an occasion where women come together to spend time in the company of each other. It provides a ground in which women get to know each other, meet new women, share informations, gossip and so on. Women usually gather once in a month (or once in every three weeks, or some other specified period) in one of the women's houses, until each woman becomes a host for once. Gün differs from other meetings and visits of women in certain respects: it involves the formation of a group and the contribution of money ${ }^{4}$ from each member. When a certain number of

\footnotetext{
${ }^{4}$ The contribution is usually in another currency than Turkish Lira, like Euro or Dollar. Otherwise, the contributions are equated to the price of a certain amount of gold. In either way, the aim is to cope with
} 
Ekal, Berna (2006) 'How a Kaynana Should Behave?' Discussions on the Role of Mothers-in-Law in Two Gün Groups', European Journal of Turkish Studies, Thematic Issue $\mathrm{N}^{\circ} 4$, The social practices of kinship. A comparative perspective, URL : http://www.ejts.org/document619.html

To quote a passage, use paragraph (§).

women start a gün (gün yapmak), they decide how much each of them will contribute each time they visit a house. Then the total amount is given to the host. It is in this sense that it can be defined as an example of rotating savings and credit associations (ROSCA): 'an association formed upon a core of participants who make regular contributions to a fund which is given in whole or in part to each contributor in turn' (Ardener 1996: 1$)^{5}$.

[5] Although other expressions like altın günü (gold day) or paralı gün (money day) are sometimes used to specify the medium of exchange in these meetings, I prefer to use the term gün to refer to this association as it came into being in the $1980 \mathrm{~s}^{6}$, for it was a term more commonly used by women in this middle class district in Istanbul. Besides, it might be useful to differentiate gün from kabul günü7 meetings: though the former has its roots in the latter (both are formal occasions in which women receive their guests in salon - the best part of the house -, dress up, and serve special food), the element of resource pooling and the character of visiting differentiates gün from kabul günü8. In

inflation, so that the women at the end of the cycle do not suffer from the depreciation of the Turkish Lira. This is also a point that Khatip-Chahidi (1996) emphasizes.

${ }^{5}$ For more examples of gün as a form of ROSCA, see Beller-Hann (1996) and Khatip-Chahidi (1996).

6 ' (...) at the end of the sixties or at the beginning of the seventies, the gün did not even exist in its present day form. At that time the kabul günü was an institution reserved for the urban elite. (...) In contrast to the kabul günü, the gün of the middle-class women of eighties is a meeting of a steady group' (Wolbert 1996: 188).

${ }^{7}$ For a thorough account of kabul günü meetings, see Benedict (1974), Aswad (1974), Lindisfarne (2001), and Özbay (1999).

${ }^{8}$ Although Wolbert recognizes the difference between kabul günü and gün while she argues that the former is arranged by elite women and the latter is by middle-class women, she still considers the two forms of meeting as 'informally regulated practice of reciprocal visits' (Wolbert: 1996, 186). What I argue, however, is that the two meetings differ in terms of the regulation of reciprocity involved in both occasions. In the kabul günü of the elite women of towns of the 1960s and 1970s, however, the host opens her house to 20 to 80 women in a particular day of each month. The guests stay about an hour in the house of the hostess where they are served food and drink, and as Benedict puts it, 'the room always appears full during a reception, and with the staggered found at such a gathering, it seems as if people are always coming and going' (Benedict 1974: 38). The patterns of attending to the kabul günü in the towns that Aswad (1974), Benedict (1974) and Lindisfarne (2001) refers to emphasize the already existing hierarchical bonds between the women in a certain area and remains a practice of elite women. In this regard, kabul günü in towns should be differentiated from gün associations in urban areas. Gün is practiced middle-class urban women with comparable statuses who set up groups, and the eligibility of each woman is negotiated before the meetings start. Usually, close neighbours or kin (who live nearby) form the initial group, while other women may join later if another member introduces them to the group. Gün, as it is practiced today in urban areas, looks more like the kabul günüs that Ferhunde Özbay (1999) recounts to have taken place in the urban middle-class houses of the first few decades of the Republican period. But still, the practice of collecting money differentiates gün from these kabul günüs in urban centres, for it offers a distinct form of regulating the visits. Although certain differences exist between the two forms of associations, some continuity can be identified as well. The ways in which the guests are welcomed, the discussions about certain issues, the serving of food, the clothes of participants and the furnishing of the 
Ekal, Berna (2006) 'How a Kaynana Should Behave?' Discussions on the Role of Mothers-in-Law in Two Gün Groups', European Journal of Turkish Studies, Thematic Issue $\mathrm{N}^{\circ} 4$, The social practices of kinship. A comparative perspective, URL : http://www.ejts.org/document619.html

To quote a passage, use paragraph $(\S)$.

gün association the equal contribution of money promises to eradicate the differences between the women in the meeting: in principle, as long as a woman can provide the specified amount of money, she can be a part of the gün. In addition, the already regulated schedule of the meetings create a sense of equality as well: gün is composed of a steady group of women (usually not more than 15 women), and each woman is visited only once during the period in which the cycle is completed. Hence, the imbalance that might arise from the failure to reciprocate a visit is avoided.

[6] Gün's distinctiveness as a woman's association is based on the idea of maintaining equivalence between the participant women through equal contribution of money, and also, through the performance of certain values. Among those values, women's observance of the boundaries of the conjugal family appears to be a significant way for them to assert their compliance with what they perceive and construct as 'modern'. The claims to observe the boundaries of the conjugal family, on the other hand, become all the more complex in the case of kaynanas: a women's memory of her 'traditional' mother-in-law stands in opposition to her own perception as a 'modern' mother-in-law. The following part of the article is meant to shed light on to this perception.

\section{II. 'How a kaynana should behave?' - Instances from the two gün meetings}

[7] The initial formation of the group, expressed with the words 'zaten tanışıyorduk'9, depends on the already constructed networks, which are based on commonalities such as living in the same building or same neighbourhood. While we were walking to the house of Firuze hanım for the first meeting of gün, I asked Sevgi hanım how she got to know the women in the area. She talked about a pattern: you might meet new women when you visit a neighbour or when you go to another gün. For instance, another woman might also come to visit the host, and you might become close with that woman 'if you like each other' ('kaynaşırsan'), and might invite her to your house as well.

[8] Neighbourhood is often strengthened with other commonalities such as coming from the same or nearby villages, or coming from the same ethnic or religious group, and so on. It is not uncommon that women might choose to form a gün group with their kinswomen. This was also the

houses are all performances of certain values in gün and kabul günü meetings. Gün and kabul günü constitute a ground for discussing, representing, or complying with middle-class values and norms for women (see Özbay: 1999 and Wolbert: 1996).

9 'We already knew each other' (my translation). 
Ekal, Berna (2006) 'How a Kaynana Should Behave?' Discussions on the Role of Mothers-in-Law in Two Gün Groups', European Journal of Turkish Studies, Thematic Issue $\mathrm{N}^{\circ} 4$, The social practices of kinship. A comparative perspective, URL : http://www.ejts.org/document619.html

To quote a passage, use paragraph $(\S)$.

pattern that could be traced in the formation of the two groups of gün. The first group of women organized gün among themselves for fifteen years. Some women left the group for several reasons like moving to another quarter, illness, or not finding the opportunity to give the money necessary to join the gün. On the other hand, some other women joined the group later. As I met the group at the end of 2004, the group consisted of ten women: four of them were eltis (wives of brothers) and two of them were sisters. Sevgi hanım's görümce (her husband's sister, Filiz) was also there. The remaining two women lived in the next building to the one that three eltis were residing. At the same time, all of these women were living in the same neighbourhood, in buildings, which were walking-distance to one another.

[9] Sevgi hanım called her other group of gün as akraba günü ('kin day') ${ }^{10}$. This was rather a small group, consisting of seven women. Although Sevgi hanım's three görümces (Filiz, Nergis and Nazik) were present, the other three women were not her relatives: Nur hanım was Filiz hanım's neighbour in her summer-house, and she lived in another nearby neighbourhood in Istanbul. The remaining two women were other neighbours from the same district that Sevgi hanım, Filiz hanım and Nergis hanım lived.

[10] Among the fifteen women whom I met in the two gün meetings, nine of the women were mother-in-law. Five of the mother-in-law lived in apartments in the same or nearby buildings to their brides or married daughters. One of the brides 'used the same kitchen' with her mother-in-law, as her husband didn't earn much. I talked to her in the kitchen of the house, a small one, where she constantly washed the dishes and tidied things. She was living in her village until she married her husband. As Sevgi hanım later commented, 'she was taken from village'. Her story is very much like the stories of other two women in the gün group that I talked to: the young men work in Istanbul until they save enough to marry and then go back to their village to find a 'suitable' wife.

[11] Even if they didn't live close by, the brides and daughters also frequented the gün meetings to help with serving guests, and this can be thought as an act of solidarity. Altorki also argues for formal visits among women that 'in these visits and others (such as death, naming, and marriage) the solidarity of women's kin group is acted out before the community... the women

\footnotetext{
10 The naming of the gün depends on how you perceive the gün group: although her kin also were there in the first group of gün, she saw the second group as a more intimate setting.
} 
Ekal, Berna (2006) 'How a Kaynana Should Behave?' Discussions on the Role of Mothers-in-Law in Two Gün Groups', European Journal of Turkish Studies, Thematic Issue $\mathrm{N}^{\circ} 4$, The social practices of kinship. A comparative perspective, URL : http://www.ejts.org/document619.html

To quote a passage, use paragraph $(\S)$.

relatives help attend guests, clean and arrange whatever escaped the attention of servants, and help the hostess to keep the glittering, spotless, generous house valued by the community. Such roles are strictly reserved for relatives and close friends bound together by commitments, obligations of support, and old friendship' (1986: 102).

[12] Sometimes mother-in-law brought their grandchildren to the gün meeting as well. As the mothers of these children worked outside home, three of the mother-in-law looked after their grandchildren regularly. This indicated that even if conjugal family was the 'norm of modernity' and the brides lived in separate households, there was still cooperation between the elders and conjugal family. On the other hand, one of the mothers-in-law expressed that she felt uncomfortable that she had to take the responsibility of her grandchildren: 'I don't know what I would do if something happens to them when their mother is at work'11, she commented. This meant that the main responsibility for a child still remained with her mother.

[13] The first time I encountered an elaboration on the role of mother-in-law was in the first meeting of akraba günü. At the time, there was a program aired on a TV channel called 'Gelinim olur musun?'12. The program had the following structure: unmarried girls, boys and mothers of the boys appeared in the program. Girls and mothers shared the same apartment, while boys stayed in a different apartment. Their every activity was broadcasted on the TV. The main idea was this: each boy chose a partner, but had to persuade his mother on the issue of marriage. As the girls and mothers lived in the same space, the mother would assess the girl on the basis of whether the girl was 'appropriate for her family'. The program was widely watched, and was a point of curiosity and discussion. In a gün meeting, one of the women recounted the latest news about 'Semra hanım,' who was then the person in the program whose behaviour was the most widely discussed in the media. Women in the gün meeting had an ambivalent approach towards her. While she represented the intolerant mother-in-law 'of the past' for many women and reminded them of their own experiences with their own kaynanas, her behaviours were also made understandable with the expression ' $\mathrm{da}$ çok çekmiş'13: she suffered as all other women did when they were young brides.

\footnotetext{
11 'Anneleri yokken başlarına bir iş gelse' (my translation).

12 'Would you be my bride?' is the name of the program (my translation).

13 'She also suffered a lot' (my translation).
} 
Ekal, Berna (2006) 'How a Kaynana Should Behave?' Discussions on the Role of Mothers-in-Law in Two Gün Groups', European Journal of Turkish Studies, Thematic Issue $\mathrm{N}^{\circ} 4$, The social practices of kinship. A comparative perspective, URL : http://www.ejts.org/document619.html

To quote a passage, use paragraph (§).

[14] However, I had the opportunity to listen to women's feelings about being a kaynana in other meetings as well. For instance, in a meeting of the first group of gün, Beyhan hanım was talking about the divorce of his son and daughter-in-law. This issue was known by other women in the meeting beforehand, so she didn't have to talk about the details much. She just commented:

[15] 'My bride was a good person. The people around her caused this situation. They didn't give her good advices. They didn't tell her to be close with her mother-in-law. We were living in the same building; she was residing in the apartment below mine. But I wouldn't see her for a week ${ }^{14}$. After three years, she distanced herself from me'15.

[16] It was in another meeting of the same group that I realized that not frequently visiting your son's or daughter's house was considered as a proper way of behaviour for a mother-in-law. Again, Beyhan hanım was talking about the divorce of his son and complaining about her daughterin-law. She told the other women that she would never force her daughter-in-law to spend time with herself. The daughter-in-law would frequently go out with her own relatives and Beyhan hanım would never say a word. Even when Beyhan hanım was ill, she wouldn't make her daughter-in-law to take care of herself. Her account was approved by the other women in the meeting. One of them commented that she also would not visit her daughter's house frequently and would never stay in her house for the night for not disturbing her husband ${ }^{16}$. Other women also claimed that they would do the same. Even if some women did not actually have married sons or daughters, they also commented on how they would behave if it was so.

[17] In gün meetings, women speak as mother-in-law, and as the structure of the meetings so permits, they can all contribute with their comments. However, I cannot recall an instance where

\footnotetext{
${ }^{14}$ Emphasis added.

15 'Benim gelinim gayet iyiydi. Bunu çevresi yaptı. Ona iyi akıl veren olmadı. Kaynananla yakın ol diyen olmadı. Benim gelinim dört dörtlüktü. Alt katımda oturuyordu ama görmüyordum bir hafta. Üç sene sonra bana mesafe koydu' (my translation).

16 In the interviews, most of the women pointed out to the fact that in the village, after the marriage, they moved to their in-laws house and did not see their own parents until the parents visited them. As a rule, the newly married bride does not see her parents until they come to visit her in the in-laws house and it is often the case that her mother do not frequently come to see her. Although this pattern reminds of the reluctance of the mother to visit her daughter's house not to disturb her husband, I argue that the two situations should be differentiated from each other. In the first situation, the newly married couple does not have a separate household, and bride's parents visit bride's in-laws as a continuation of marriage transactions. In the other situation, however, the couple has a separate household.
} 
Ekal, Berna (2006) 'How a Kaynana Should Behave?' Discussions on the Role of Mothers-in-Law in Two Gün Groups', European Journal of Turkish Studies, Thematic Issue $\mathrm{N}^{\circ} 4$, The social practices of kinship. A comparative perspective, URL : http://www.ejts.org/document619.html

To quote a passage, use paragraph (§).

the issue of being a kaynana was brought forward in the presence of a daughter or a bride. This was perhaps because mother-in-law usually talked about their uncertainty with how to behave towards their brides, and they usually asserted that they couldn't see why problems came out, as they thought they did everything to respect the space of their brides and the boundaries of their conjugal family. In gün meetings mother-in-law' own experience as brides is unspoken, yet their experiences provide a frame of reference in articulating their own claims to be 'modern' mother-in-law. To understand that frame of reference, I asked the mother-in-law about their own experience as brides in the interviews.

[18] These women usually lived with their in-laws in their first years of marriage. The creation of a separate household was usually made possible with rural to urban migration. However, some of the women had to live with their in-laws even after the migration. In both cases, the older form of living arrangement seemed difficult to live with. For instance, in one of the interviews, Canan hanım recounted her days in the house that she lived with her in-laws:

[19] 'When your ideas with your mother-in-law do not match, it becomes really bad. For instance, you might be late in going to the stable, I was recently married. (...) I was 20 when I got married. Your own parents would treat you gentle. They kindly ask you to help with the housework. When you go to somebody else's house, it is not like that. [They tell you:] 'Why did you get married, then, if you do not know how to cook?' You feel resentful, then. Now, it is not like that ${ }^{17}$. Whether or not a girl knows it, her spouse would accept her like that. Mothers-in-law are also like that. They help the daughter-in-law, would treat her gently. It would have been better if we were to marry now. Well, of course, if your mother-in-law is not a considerate person, it does not differ whether you get married now or back then. I wouldn't treat my daughter-in-law like that if I had one now. (...) There in the village, we had a lot of work. Maybe it was because we had so much to do. If we were to live like this [with relatively less housework to do], we wouldn't have so much trouble'18.

\footnotetext{
${ }^{17}$ Emphasis added.

18 'Ahıra geç gidiyorsun, yeni evlenmişsin. (...) 20 yaşında evlendim ben. Annen baban 0 kadar rahat davranıyor ki sana. Hadi canım gülüm, kalk şu işi yap, şöyle yap böyle yap. Elin evine gittiğin zaman öyle yapmıyorlar. Hadi, yemek yapmasını bilmiyorsun da kocaya nasıl geldin? İster istemez insan kırlıyorsun, şey yapıyorsun. İlla kocaya gitmek için birşeyler bilmen lazımmış. Şimdi öyle birşey yok. Bilse de bilmese de eşi onu kabul ediyor. Kayınvalide öyle, onlara yardımcı oluyorlar yani, hoş karşılıyorlar. Şimdi evlensek daha şey olurdu, yani kayınvalide anlayışı olmasa, şimdi evlensen de farketmez yani. Herkese anlayışlı kayınvalide kısmet olsun. Benim şu an gelinim olsa bana yapılanların hiçbir tanesini yapmam. (...) Dağa ekin biçmeye
} 
Ekal, Berna (2006) 'How a Kaynana Should Behave?' Discussions on the Role of Mothers-in-Law in Two Gün Groups', European Journal of Turkish Studies, Thematic Issue $\mathrm{N}^{\circ} 4$, The social practices of kinship. A comparative perspective, URL : http://www.ejts.org/document619.html

To quote a passage, use paragraph (§).

[20] When the new couple lives in the house of the mother-in-law, tension arises due to the way in which housework is to be done. Mercan hanım, who lived with her mother-in-law for six years, recounted how she thought a proper relation between a mother-in-law and a daughter-in-law should be:

[21] 'In fact, you shouldn't have problems with your mother-in-law. If you are a reasonable person, you know that you need an elder person. It is not easy for two people to become friends. For instance, when I came to their house, they already had an order. They have an order, right? They put the glass like this, I put it like that. What I did would disturb her and what she did would disturb me. I mean, we didn't have much enmity, but she would ask me why I didn't put something away. I would answer: 'mother, I was taking care of the children'. If I were more practical, if I would be quicker to tidy the things when the children threw things away - maybe it was because of me as well. If there is something wrong, it is not only one-sided. You cannot accord with their order. But you should. If you came to her house, you should comply with her rules. Or if you are going to stay, you will not respond to what is said to you. (...) Everyone has a different background. They come to one house without knowing each other. Everyone has a different view, a different sense. Everyone eats differently, sleeps differently, tidies the house differently, does the cleaning differently. Everyone does the housework differently. But the mother-in-law should also consider the bride as a human, do not talk much about her behaviours, think that the bride would grow up and get used to there. She should be tolerant' 19 .

gidiyordun, tarlada bağda bahçede elma topla. İşimiz çoktu, o sıkıntıdan, iş nedeniyle. Aynı bura gibi oturuyor olsaydık, bunların hiçbir tanesi olmazdı' (my translation).

19 'Kaynanamla sorunlar aslında, kaynanamla sorunlar olmaması gerekiyor. Niçin olmaması gerekiyor? Akı başındaolan bir insan, büyük bir insana intiyacı vardır. Şimdi öyle birşey oluyor ki ne kadar olsa ayrı ayrı yerlerden gelmişsin. İki insanın arkadaşlık kurması kolay değil. Mesela ben onların düzeninin üstüne geldim. Onların bir düzeni var değil mi, sen bardağı böyle korsun ben böyle korum. Benim yaptığım onunkine batardı onunki benimkine batardı. Batma sebebi de yine yani çok öyle bir aramızda sürtüşme olmazdı da kızım işte şunları niçin kaldırmadın derdi. Ben de derdim ki anne çocuklar durmadı kaldıramadım. Veyahut da daha pratik davranmış olsaydım, çocuklar gelirler dökerler kırarlar ben burayı çabucak kaldırayım, belki de benden de kaynaklanıyordu. Hiçbir zaman haksızlık tek taraflı değildir. Çünkü uyum sağlayamazsın. Niçin sağlayamazsın? $\mathrm{O}$ insanın düzenini bozuyorsun. Gelmişsin. Sen onun düzenine göre ayak uyduracaksın. Ya da evine geldiysen onunla beraber kalacaksan her söylenene susacaksın. (...) Çünkü insanların hep anlaşma şeysi ayrı ayrı yerlerden. Birbirlerini tanımadan bilmeden. Herkesin görüşü ayrıdır, aklı fikri ayrıdır. Yemek yemesi ayrıdır, yatması uyuması ayrıdır, ev toplaması ayrıdır. Temizliği ayrıdır. Bütün herkesin işi birbirini tutmaz. Ama bu da insan, ben buna ses çıkarmayayım, bu da yanımıza geldi, bu da burada büyüyecek 
Ekal, Berna (2006) 'How a Kaynana Should Behave?' Discussions on the Role of Mothers-in-Law in Two Gün Groups', European Journal of Turkish Studies, Thematic Issue $\mathrm{N}^{\circ} 4$, The social practices of kinship. A comparative perspective, URL : http://www.ejts.org/document619.html

To quote a passage, use paragraph $(\S)$.

[22] The form of living arrangement that entailed the new couple to live with the husband's family required that the mother-in-law and the bride would carry out the housework together. The women in the interviews usually identified this circumstance as the cause of the tension. In a comparable context, Sirman argues that the tension arises due to the fact that the sharing of the domestic space enables the mother-in-law to exert control over the bride and also this makes the bride's labour invisible as the mother-in-law 'receives all the credit for a smoothly running household' (Sirman 1995: 209).

[23] But women claim that 'now' it is different: 'now' it does not matter even if you do not know how to do the housework. This emphasis, together with the emphasis in the gün meetings that the mother-in-law should not visit the house of her son or daughter frequently and with the emphasis in the interviews on how a mother-in-law should behave towards the bride (be considerate), suggests that women distinguish different forms of behaving as a mother-in-law. They characterize the mothers-in-law 'in the past' as intolerant. But 'now', first of all, a mother-in-law should be tolerant towards the bride. Secondly, she should not visit frequently the bride's house, as well as her own daughter's house. This articulation is not necessarily a means to eradicate the power relations between mothers-in-law and the brides, but can be thought as another way of maintaining that relation, albeit in a 'modern' form.

\section{Maintaining the Boundaries of the Conjugal Family}

[24] The relation between the mother-in-law and the bride / or the groom is ultimately about the role each person plays in the formation of a separate unit through marriage. Hence, the statements on 'how a mother-in-law should behave?' are, above all, about the production of a certain position of kaynana within the discourse through which the boundaries of this unit is drawn. The statements in the gün meetings and in the interviews (the 'tolerance' that the mother-in-law should have towards the bride and the reluctance that she should employ towards visiting the couple's house) suggest that women take conjugal family as a unit whose privacy and boundary should not be disturbed. I argue that the discussions on the 'proper' way of acting as a kaynana, who respects the 
Ekal, Berna (2006) 'How a Kaynana Should Behave?' Discussions on the Role of Mothers-in-Law in Two Gün Groups', European Journal of Turkish Studies, Thematic Issue $\mathrm{N}^{\circ} 4$, The social practices of kinship. A comparative perspective, URL : http://www.ejts.org/document619.html

To quote a passage, use paragraph $(\S)$.

boundary of this unit, have very much to do with the perception of conjugal family, who lives in a separate household, as the norm of a modern way life.

[25] For Tomlinson, apart from the political-economic processes of modernization, there are 'the great cultural narratives of modernity: the collective stories we tell ourselves about our experience, the possibilities of fulfilment we see for ourselves, our common conceptions of human goals, and so on. These cultural 'imaginings' do not spring from some 'inner dynamic' of human self development; they are, rather, stories about development itself - attempts at social selfunderstanding valorised and preserved within the interpretive texts of a culture' (Tomlinson 1991: 153). It is in this sense that women's perception of conjugal family can be thought as a collective story of social self-understanding: while their experiences in the house that they shared with their mother-in-law are identified as a thing of the 'past', conjugal family (who lives in a separate household) appears as a more autonomous unit from the families that both the husband and wife come from, hence from kinship ties.

[26] The traces of this self-understanding can be followed in the narrative of modernity in Turkey. In the formation of the nation-state, women and conjugal family constituted the core in the discursive practices that became constitutive in different contexts such as the formation of the everyday practices or other institutions through which Turkey was to be modernized. Sirman argues that the nation-state sought to regulate sexuality on the basis of love and conjugal family: 'in this type of social order, the conjugal family, rather than the house, becomes the unit that sustains both the political and the gender regime. The individual owed his or her allegiance only to the nation state, with the family as the only recognized mediating structure. Individuals within this family were to be bound to one another by no other tie but love, a relationship they would enter into out of their own volition' (Sirman 2004a: 48). Although conjugal family becomes the only legally recognized unit20, we can envisage from the life stories of the mothers-in-law in the gün meetings that it only gradually started to dominate the collective stories of marriage, family and household patterns.

20 Sirman argues: 'The Turkish Republic institutionalized this arrangement by promulgating its civil code in 1926 whereby the (conjugal) family was proclaimed as the constituent unit of the polity and no other bonds that linked persons to one another were recognized legally. The individual owed his or her allegiance only to the nation state, with the family as the only recognized mediating structure' (Sirman 2004b: 10). 
Ekal, Berna (2006) 'How a Kaynana Should Behave?' Discussions on the Role of Mothers-in-Law in Two Gün Groups', European Journal of Turkish Studies, Thematic Issue $\mathrm{N}^{\circ} 4$, The social practices of kinship. A comparative perspective, URL : http://www.ejts.org/document619.html

To quote a passage, use paragraph $(\S)$.

[27] Conjugal family is never a fully autonomous, complete and closed unit. The fulfilment of this norm requires constant negotiation between the members of the conjugal unit and kin. The relation between the bride and the mother-in-law is the most noticeable form of this negotiation. Kandiyoti and Sirman discuss the relation between the bride and the mother-in-law where the two share the domestic space. Kandiyoti $(1988 ; 1998)$, for instance, discusses the relations between mothers-in-law and brides within the framework of women's empowerment strategies in patriarchy. She argues that women's life cycle implies that as young brides women experience hardship and they acquire power as they become mother-in-law21, hence, 'the cyclical nature of women's power in the household and their anticipation of inheriting the authority of senior women encourages a specific kind of identification with the system of hierarchy' (Kandiyoti 1998: 143). Sirman (1995) also discusses the struggle between mothers-in-law and brides in shared domestic space in the context of a village of Western Anatolia. She argues that mothers-in-law aim to sustain the networks they already have and also aim to secure themselves in old age. Brides, on the other hand, aim autonomy for themselves and for their marital unit.

[28] As can be inferred from the interviews, women in the gün meetings have been through such experiences of sharing the domestic space with their mother-in-law. The conflict between mothers-in-law and brides over the housework in shared domestic spaces seems to be resolved by the creation of a separate household. Forming a separate household that is directed towards gaining autonomy for the conjugal unit might be a common strategy in urban as well as in rural areas. However, when we consider women's relations with their own daughters and daughters-in-law, we deal with a different framework where young brides already established their separate households. Canan hanım's remark that 'now' it does not matter whether a bride knows how to do housework or not can be thought in such a context: 'now', the existence of separate households seems to make the arguments over housework groundless. Although it needs further study to look at how the conflicts between the brides and mothers-in-law are shaped in such a context, the conversations in the gün meetings still provide us with an idea of how the role of kaynana is conceptualized in middle-class circles of women who experienced rural to urban migration. Here, then, we do not deal with the

\footnotetext{
${ }^{21}$ Here I do not go into the details of Kandiyoti's argument where she aims to develop a theory to capture the specific character of gender. I only refer to the way in which she conceptualizes the position of mother-in-law.
} 
Ekal, Berna (2006) 'How a Kaynana Should Behave?' Discussions on the Role of Mothers-in-Law in Two Gün Groups', European Journal of Turkish Studies, Thematic Issue $N^{\circ} 4$, The social practices of kinship. A comparative perspective, URL : http://www.ejts.org/document619.html

To quote a passage, use paragraph (§).

strategies of the creation of a separate household, but how the affirmation of the norm of separate households is constitutive in the self-perception of women.

[29] The discussions in gün meetings, first of all, provide us with what is the meaning of being a kaynana in middle-class urban neighbourhoods where the norm of conjugal family prevails. This drives our attention to the changing meaning of kinship roles with the changing imaginary of peoples: while the kaynana of the 'old times' requires an obedient bride to continue with her already built networks, the newly imagined kaynana refrains from such demands. Through the rejection of the 'older' role of kaynana, what is perceived as the modern role of kaynana is constructed. This brings us to the idea that kinship roles are not timeless entities that denote a certain form of relation among individuals. Rather, as the kaynana role indicates, they are open to change and open to different interpretations.

[30] Secondly, for a mother-in-law, her claim to observe the boundaries of the conjugal family defines her relation to the wife of her son / the husband of her daughter and positions herself as an urbane, considerate, or proper person - definitions bound to the meaning of what is perceived to be modern. For the women in the gün meetings, conjugal family provides the discursive framework within which they position themselves as kaynanas vis-à-vis the newly married couples. In the context of gün, her claim is also what makes her a part of the urban middle-class. Your idea of how kinship roles should be, then, not only regulates your relationship to your kin, but also affects your relation to the people other than your kin. Maintaining the boundaries of the conjugal family, then, becomes not only the concern of the newly married couple in terms of gaining autonomy: observing this boundary becomes the defining feature of a modern woman in her role as a kaynana. 
Ekal, Berna (2006) 'How a Kaynana Should Behave?' Discussions on the Role of Mothers-in-Law in Two Gün Groups', European Journal of Turkish Studies, Thematic Issue $\mathrm{N}^{\circ} 4$, The social practices of kinship. A comparative perspective, URL : http://www.ejts.org/document619.html

To quote a passage, use paragraph (§).

\section{References}

Abu-Lughod, Lila (2000) 'Modern Subjects: Egyptian Melodrama and Postcolonial Difference' in Mitchell, Timothy (ed) Questions of Modernity, Minneapolis, University of Minnesota Press.

Ardener, Shirley (1996) 'Women Making Money Go Round: ROSCAs Revisited' in Ardener, Shirley; Burman, Sandra (eds.) Money-Go-Rounds: The Importance of Rotating Savings and Credit Institutions, Oxford/Washington D.C., Berg.

Aswad, Barbara C. (1974) 'Visiting Patterns among Women of the Elite in a Small Turkish City' Anthropological Quarterly, 47(1).

Beller-Hann, Ildiko (1996) 'Informal Associations Among Women in North-East Turkey' in RasulyPaleczek, Gabriele (ed) Turkish Families in Transition, Frankfurt am Main/Berlin/Bern/New York/Paris/Wien, Peter Lang.

Benedict, Peter (1974) 'The Kabul Günü: Structured Visiting in an Anatolian Provincial Town', Anthropological Quarterly, 47(1).

Bruner, Jerome (1991) 'The Narrative Construction of Reality', Critical Inquiry, vol. 18.

Kandiyoti, Deniz (1988) 'Bargaining with Patriarchy', Gender and Society 2(3).

Kandiyoti, Deniz (1998) 'Gender, Power and Contestation: 'Rethinking Bargaining With Patriarchy", in Jackson, C. and Pearson, R. (eds.) Feminist Visions of Development, London, Routledge.

Khatip-Chahidi, Jane (1996) 'Gold Coins and Coffee ROSCAs: Coping With Inflation the Turkish Way in Northern Cyprus' in Ardener, Shirley; Burman, Sandra (eds.) Money-Go-Rounds: The Importance of Rotating Savings and Credit Institutions, Oxford/Washington D.C., Berg.

Lindisfarne, Nancy (2002) Elhamdülillah Laikiz: Cinsiyet, İslam ve Türk Miliyetçiliği, İstanbul, İletişim Yayınları.

Mitchell, Timothy (2000) 'The Stage of Modernity' in Mitchell, Timothy (ed) Questions of Modernity, Minneapolis, University of Minnesota Press.

Rofel, Lisa (1999) Other modernities: gendered yearnings in China after socialism, Berkeley, University of California Press.

Sirman, Nükhet (1995) 'Friend of Foe? Forging Alliances with Other Women in a Village of Western Turkey', in Tekeli, Şirin (ed) Women in Modern Turkish Society: A Reader, London, Zed Books.

Sirman, Nükhet (2002) 'Kadınların Milliyeti' in Bora, Tanıl (ed) Modern Türkiye'de Siyasi Düşünce Cilt 4: Milliyetçilik, İstanbul, Iletişim Yayınları.

Sirman, Nükhet (2004a) 'Kinship, Politics, and Love: Honour in Post-Colonial Contexts - The Case of Turkey' in Mojab, Shahrzad; Abdo, Nahla (eds.) Violence in the Name of Honour: Theoretical and Political Challenges, İstanbul, Bilgi University Press.

Sirman, Nükhet (2004b) 'Intimate Publics: Equality and Competition among Strangers in Turkish Society' Paper presented to the workshop on Prises de risques en famille: la parenté a l'épreuve de l'économie et du politique de l'Iran aux Balkans, Istanbul, 7-8 May 2004. 
Ekal, Berna (2006) 'How a Kaynana Should Behave?' Discussions on the Role of Mothers-in-Law in Two Gün Groups', European Journal of Turkish Studies, Thematic Issue N4, The social practices of kinship. A comparative perspective, URL : http://www.ejts.org/document619.html

To quote a passage, use paragraph (§).

Özbay, Ferhunde (1999) 'Gendered Space: A New Look at Turkish Modernization' Gender \& History 11(3).

Tomlinson, John (1991) Cultural Imperialism: A Critical Introduction, Baltimore, John Hopkins University Press.

Wolbert, Barbara (1996) 'The Reception Day: A Key to Migrant's Reintegration' in Rasuly-Paleczek, Gabriele (ed) Turkish Families in Transition, Frankfurt am Main/Berlin/Bern/New York/Paris/Wien, Peter Lang. 